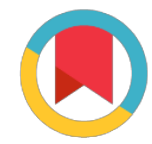

Check for updates

*For correspondence:

chethicamha@yahoo.com

Competing interests: The authors declare that no competing interests exist.

Received: 2017-07-05

Accepted: 2017-08-05

Published: 2017-09-05

Copyright The Author(s) 2017. This article is published with open access by BioMedPress (BMP).

This article is distributed under the terms of the Creative Commons Attribution License (CC-BY 4.0) which permits any use, distribution, and reproduction in any medium, provided the original author(s) and the source are credited.

\section{Hydrothermal synthesis of carbon nanodots from millets for cancer cells imaging}

\author{
Quang Ngo Khoa, Tran Thi Xuan Thuy, Che Thi Cam Ha \\ Hue College of Sciences, Hue City, Vietnam
}

\section{Abstract}

We presented a green, simple and economical method to synthesize carbon nanodots (C-dots) from millets using hydrothermal synthesis route. The obtained C-dots have average diameter ranging from 6 to $8 \mathrm{~nm}$. Optical measurements showed the formation of hydroxyl, carbonyl/carboxyl, amino functional groups on the particle surfaces, resulting in their high hydrophilicity and bioconjugation. After treatment with C-dots, human cervical and lung cancer cells became bright and exhibited multicolor fluorescence under different excitation wavelength. The achievement demonstrated potential applications of fluorescent C-dots in the field of biomedical application, especially in diagnostic disease techniques.

\section{Keywords}

Carbon nanodots, Photoluminescence, Natural biomass, Millets, Hydrothermal method, Biomedical application, human cervical cancer cells, lung cancer cells.

\section{Funding}

\section{References}

1) Xiaohu G, Lily Y, John AP, Fray FM, Jonathan WS and Shuming N (2005) In vivo molecular and cellular imaging with quantum dots. Curr. Opin. Biotechnol 16:63-72 2) Murray CB, Norris DJ, Bawendi MG (1993) Synthesis and characterization of nearly monodisperse CdE (E = sulfur, selenium, tellurium) semiconductor nanocrystallites. J Am Chem Soc 115(19):8706-87153

3) He Y, Lu HT, Sai LM, Su YY, Hu M, Fan CH, Huang W, Wang LH (2008) Microwave synthesis of water-dispersed $\mathrm{CdTe} / \mathrm{CdS} / \mathrm{ZnS}$ core-shell-shell quantum dots with excellent photostability and biocompatibility. Adv Mater 20(18):3416-3421

4) Sheila NB and Gary AB (2010) Luminescent carbon nanodots: emergent nanolights. Angew. Chem. Int. Ed. 49:6726-6744

5) Haitao L, Zhenhui K, Yang L and Shuit TL (2012) Carbon nanodots: synthesis, properties and applications. J. Mater. Chem 22:24230-24253 